\title{
The Effect Of The Implementation Of Puerperium Intensive Care On Exclusive Breastfeeding
}

\author{
Yunik Windarti*, Rizki Amalia \\ Faculty of Nursing and Midwifery, Nahdlatul Ulama University of Surabaya, Indonesia \\ *yunikwinda@unusa.ac.id
}

\begin{abstract}
Exclusive breastfeeding is one of the programs that grabs attention, where it is known that its achievements have never been successful according to the target that has been announced by the Indonesian government. This requires a large joint commitment from the government, private sector, and society. In addition to target achievement solutions, the important thing for the success of the program is the postpartum mother herself, where with intensive care and fulfillment of her needs it is hoped that it will encourage mothers to provide exclusive breastfeeding. The aim of this study was to analyze theeffect of puerperium intensive care on the achievement of exclusive breastfeeding. The research design was a quasi experimental design form nonequivalent control group design.independent variables Puerperalin the intensive care and the dependent variableexclusive breastfeeding. The population of post-partum mothers using nonprobability sampling technique with incidental sampling for 6 months in Wonokromo Surabaya in 2020, the research instrument with a questionnaire. Data were analyzed using the chi-square test. The results showed that most of the 62 respondents $(54.84 \%)$ did not provide exclusive breastfeeding. Of the 31 respondents who received puerperium intensive care, most $(58.06 \%)$ gave exclusive breastfeeding, of the 31 respondents who did not receive puerperium intensive care, most $(67.74 \%)$ did not provide exclusive breastfeeding. The $\mathrm{p}$ value $=0.041<\alpha=0.05$ means that there is an effect of puerperium intensive care on the achievement of exclusive breastfeeding.
\end{abstract}

Keywords : Exclusive Breastfeeding, Puerperium Intensive Care 


\section{STRADA Jurnal Ilmiah Kesehatan}

DOI: $10.30994 /$ sjik.v9i2.402

ISSN: 2252-3847 (print); 2614-350X (online)

Vol.9 No.2 November 2020 Page.970-975

\section{BACKGROUND}

The birth of a baby is something that is very much awaited and a source of family happiness. Various efforts have been made by health workers, families and the government to keep mothers and babies in good health, one of which is by giving exclusive breastfeeding. However, data shows that babies who were exclusively breastfed in East Java in 2018 amounted to 76.98\%, which is still far from the target (KemenkesRI, 2019). Various factors cause this problem, one of which is the commitment of the mother in giving exclusive breastfeeding. Not all mothers give breast milk only for 6 months for various reasons. Hard work, smart work, good cooperation, and high commitment are needed to increase the achievement of these targets. One effort that can be done is to provide intensive attention and care for postpartum mothers starting from the first day after delivery, namely by giving a massage to the mother's head so that the mother feels comfortable, caring for the breast and teaching techniques to breastfeed the baby properly, providing oxytocin massage, teaching breast exercises, and provide health education for postpartum and breastfeeding mothers. The fact is that intensive care after childbirth is currently lacking. For example, regarding breast care or breast masage to facilitate breastfeeding. Post-partum mothers tend to take care only when there are complaints. Therefore, intensive care by health workers and families is needed.

This study aims to analyze theeffect of puerperium intensive care application on the achievement of exclusive breastfeeding.

\section{METHODS}

The research design used a quasi experimental design form nonequivalent control group design.independent variable Puerperium intensive care (divided into 2 groups, namely the treatment group and did not receive puerperium intensive care treatment) and the dependent variable exclusive breastfeeding. The population and sample in this study were 62 postpartum mothers. Samples were taken using nonprobability sampling technique with incidental sampling for 6 months in Wonokromo Village, Surabaya, East Java in 2020. The data used were primary data with a questionnaire instrument. Data were analyzed using the chi-square test with the help of SPSS. This research has passed the ethical test with ethical clearance number 102 / EC / KEPK / UNUSA / 2020 by the Health Research Ethics Commission of the Nahdlatul Ulama University Surabaya.

\section{RESULTS}

The results showed that of the 62 respondents half $(50 \%)$ received puerperium intensive care, half $(50 \%)$ did not receive puerperium intensive care, most $(54.84 \%)$ respondents did not exclusively breastfeed, and almost half $(45.16 \%)$ provide exclusive breastfeeding. Of the 31 respondents who received puerperium intensive care, the majority (58.06\%) gave exclusive breastfeeding and almost half $(41.94 \%)$ did not exclusively breastfeed. Of the 31 respondents who did not receive puerperium intensive care, most $(67.74 \%)$ did not provide exclusive breastfeeding and almost half $(32.26 \%)$ gave exclusive breastfeeding. Of the 62 respondents in this study, almost all (87.1\%) were of reproductive age and a small proportion $(12.9 \%)$ were of high risk age, most $(66.1 \%)$ were multiparous and almost half $(33.9 \%)$ were primiparous, most $(67.7 \%)$ were unemployed and almost half $(32.3 \%)$ work, most $(72.5 \%)$ have secondary education, a small proportion $(6.5 \%)$ have basic education, and a small proportion $(21 \%)$ have higher education. The $\mathrm{p}$ value $=0.041<\alpha=0.05$ means that there is an effect of puerperium intensive care on the achievement of exclusive breastfeeding. 


\section{STRADA Jurnal Ilmiah Kesehatan}

DOI: $10.30994 /$ sjik.v9i2.402

ISSN: 2252-3847 (print); 2614-350X (online)

Table 1 Frequency distribution of respondents based on puerperium intensive care

No Puerperium intensive care Frequency Percentage (\%)

\begin{tabular}{cccc}
\hline 1 & Yes & 31 & 50 \\
2 & No & 31 & 50 \\
\hline Total & & 62 & 100 \\
\hline
\end{tabular}

Table 1 shows that of the 62 respondents half $(50 \%)$ received puerium intensive care treatment

Table 2 Frequency distribution respondents by the achievements of exclusive breastfeeding

\begin{tabular}{lccc}
\hline No. & achievement exclusive breastfeeding & Frequency & Percentage (\%) \\
\hline 1 & Yes & 28 & 45.16 \\
& 2 & 34 & 54.84 \\
\hline Total & & 62 & 100
\end{tabular}

Table 2 shows that out of 62 respondents the majority (54.84\%) of respondents did not give exclusive breastfeeding

Table 3 cross tabulation of pengaruh application puerperium intensive care for exclusive breastfeeding achievements

\begin{tabular}{lccc}
\hline & \multicolumn{2}{c}{ Achievements exclusive breastfeeding } & \multirow{2}{*}{$\begin{array}{c}\text { Total } \\
\text { Puerperium Intensive Care }\end{array}$} \\
\cline { 2 - 3 } & $\begin{array}{c}\text { No } \\
\mathrm{n}(\%)\end{array}$ & $\begin{array}{c}\text { Yes } \\
\mathrm{n}(\%)\end{array}$ & \\
\hline No & $21(67.74)$ & $10(32.66)$ & $31(100)$ \\
\hline Yes & $13(41.94)$ & $18(58.06))$ & $31(100)$ \\
\hline Total & $34(30.43)$ & $28(69.57)$ & $62(100)$ \\
\hline
\end{tabular}

Table 3 shows that of the 31 respondents who did not receive puerperium intensive care, the majority $(67.74 \%)$ did not provide exclusive breastfeeding. Usif and of the 31 respondents who received puerperium intensive care treatment, most $(58.06 \%)$ gave exclusive breastfeeding.

Table 4 Frequency distribution of respondents by age

\begin{tabular}{cccc}
\hline No & Age & Frequency & Percentage (\%) \\
\hline 1 & Reproductive (20 - 35 years) & 54 & 87.1 \\
2 & High risk (<20 years or $>35$ years & 8 & 12.9 \\
\hline Total & 62 & 100 \\
\hline
\end{tabular}

Table 4 shows thatof the 62 respondents almost all( $87.1 \%)$ of childbearing age

Table 5 frequency distribution of respondents by parity

\begin{tabular}{llcc}
\hline No & parity & frequency & Percentage $(\%)$ \\
\hline 1 & Primiparas & 21 & 33.9 \\
2 & Multipara & 41 & 66.1 \\
\hline \multicolumn{2}{l}{ Total } & 62 & 100 \\
\hline
\end{tabular}

Table 5 shows that out of 62 respondents the majority (66.1\%) multipara

Table 6 The frequency distribution of respondents by occupation 


\section{STRADA Jurnal Ilmiah Kesehatan}

DOI: $10.30994 /$ sjik.v9i2.402

ISSN: 2252-3847 (print); 2614-350X (online)

Vol.9 No.2 November 2020 Page.970-975

\begin{tabular}{cccc}
\hline No & Job & Frequency & Percentage (\%) \\
\hline 1 & Not working & 42 & 67.7 \\
2 & Working & 20 & 32.3 \\
\hline \multicolumn{2}{l}{ Total } & 62 & 100 \\
\hline
\end{tabular}

Table 6 shows that most of the 62 respondents (67.7\%) do not work

Table 7 Distribution of frequency of respondents based on education

\begin{tabular}{clcc}
\hline No & Education & Frequency & Percentage (\%) \\
\hline 1 & Basic & 4 & 6.5 \\
2 & Middle & 45 & 72.5 \\
3 & High & 13 & 21 \\
\hline \multicolumn{2}{l}{ Total } & 62 & 100
\end{tabular}

Table 7 shows that most of the 62 respondents $(72.5 \%)$ had a secondary education

\section{DISCUSSION}

Research conducted on 62 respondents revealed the results that most (54.84\%) mothers did not exclusively breastfeed. There are many constraints that are the determining factors for mothers to give exclusive breastfeeding, namely social, cultural, economic, age, parity, family support, and support from health workers (Sohimah \& Lestari, 2017). Based on the questionnaire recapitulation, the mother did not give exclusive breastfeeding, there were 3 reasons that were most often stated, namely because it did not flow smoothly, felt that breast milk was not enough for her baby, the family gave other drinks (plain water and formula milk). This is in line with the results of the study which states that family support affects exclusive breastfeeding with a value of $p=0.002$ (Umami \& Margawati, 2018). Some of the reasons that this mother conveyed could actually be given a solution by providing good communication on intervention education (IEC), for example regarding breast milk that was not smooth or breastmilk did not come out, starting to be prepared since pregnancy by carrying out breast care. During the puerperium, breast care is rarely done by the mother if there are no problems. The resultsshowed that the proportion of women receiving specific interventions during maternal PNC was mostly low (41.81\% for breast exam) (Kim, Singh, \& Weiss, 2019). In accordance with the IEC regarding the nutritional needs (ASI) of newborns, it can be a preventive solution to complaints of mothers who feel that their baby is not getting enough breast milk. IEC about the benefits of breastfeeding for mothers and families together will influence the understanding of mothers and their families how important it is to breastfeed only mothers and babies.

After cross-tabulation, it turns out that 31 respondents who received puerperium intensive care treatment mostly $(58.06 \%)$ gave exclusive breastfeeding to their babies. Intensive care during the postpartum period is care that is carried out to post-partum mothers from the health service to the home by involving the family which is carried out intensively (Windarti \& Dewi, 2020). In this study, postpartum mothers were given intervention in the form of head relaxation massage on the first day of childbirth, continued breast care and taught the correct technique of breastfeeding the baby on the second day. On the 4th day, they were given oxytocin massage, and on the 7th day, breast exercises were taught. This head relaxation massage aims to increase endorphin hormones, improve blood circulation, provide a sense of comfort and relaxation, and build positive thoughts. Breast care is carried out to maintain cleanliness, facilitate and increase milk production. Breastfeeding techniques are taught to mothers so that when breastfeeding 


\section{STRADA Jurnal Ilmiah Kesehatan}

DOI: $10.30994 /$ sjik.v9i2.402

ISSN: 2252-3847 (print); 2614-350X (online)

Vol.9 No.2 November 2020 Page.970-975

their babies can be done properly and optimally, avoiding blistered nipples and maximum milk out. Oxytocin massage aims to facilitate breastfeeding, provide comfort to the mother, accelerate uterine involution, and increase endorphin hormones. Breast exercise is carried out with the aim of making the breasts less prone to sagging, increasing mother's confidence, and maintaining breast aesthetics.

Almost all respondents in this study $(87.1 \%)$ were of reproductive age. This reproductive age ranges from 20 - 35 years. This age is the best age to have children. At this age the mother is still physically strong and psychologically mature enough to care for and pay attention to her baby. The results showed that respondents aged 18 - 35 years were more likely to breastfeed their babies than respondents aged $<18$ years, statistically there was an effect between maternal age and breastfeeding (Dewi, 2016). Apart from age, it is known that most $(66.1 \%)$ respondents are multiparous. Multiparous means a mother who has given birth to more than one child. In general, this multiparous mother already has experience in breastfeeding or raising children, so it is hoped that she will be able to provide exclusive breastfeeding.respondents Most of the $(72.5 \%)$ have secondary education. In general, education will affect one's knowledge. Middle or high school education is sufficient as a provision to gain good knowledge, enough to be able to easily understand information so that health education comes from printed media, electronic media, as well as from health workers. Like the statement of the research results that respondents who have good knowledge tend to give exclusive breastfeeding to their babies, the $\mathrm{p}$ value is obtained $=0.043$ (Amir, Nursalim, \& Widyansyah, 2018). It is known that most of the respondents (67.7\%) do not work. Being a housewife is something that many respondents do. Even though she doesn't work, household chores such as sweeping, washing, cooking, etc., take up quite a bit of mother's time. Plus you have to take care of the baby, husband, and maybe other family members. Mothers who do not work tend to be more attentive and breastfeeding better than mothers who are working. Unlike working mothers, more preparation is needed to be able to provide breast milk, starting from pumps, breastfeeding boxes, etc., especially the commitment to breastfeeding. This is in accordance with the results of research which states that exclusive breastfeeding at 6 months was less likely to be practiced by working mothers (Alzaheb, 2017).

The SPSS results obtained $p$ value $=0.041$. So that $p=0.041<\alpha=0.05$ means that there is an effect of the application of puerperium intensive care on the achievement of exclusive breastfeeding. A postpartum mother after being given intensive care puerperium intervention affects the mother both psychologically and physically so that the mother succeeds in giving exclusive breastfeeding. Physically, the mother is healthier and psychologically she feels more comfortable and calm, which increases the happiness hormone or endorphin.

\section{CONCLUSION}

The conclusion in this study is that there is a significant effect of the application of puerperium intensive care on the achievement of exclusive breastfeeding. When mothers receive puerperium intensive care interventions, the opportunities for mothers to exclusively breastfeed their babies are greater. It is hoped that health workers, families, and post-partum mothers will want to implement puerperium intensive care to improve health status while at the same time supporting government programs so that the target of exclusive breastfeeding is achieved. 


\section{STRADA Jurnal Ilmiah Kesehatan}

DOI: $10.30994 /$ sjik.v9i2.402

ISSN: 2252-3847 (print); 2614-350X (online)

Vol.9 No.2 November 2020 Page.970-975

\section{REFERENCES}

Alzaheb, R. (2017). Factors Influencing Exclusive Breastfeeding in Tabuk, Saudi Arabia. Clinical medicine insights. Pediatrics, 11, 1179556517698136.

Amir, A., Nursalim, \& Widyansyah, A. (2018). Faktor-faktor yang mempengaruhi pemberian asi pada bayi neonatal di rsia pertiwi makassar. Media Gizi Pangan, 25(1), 47-54.

Dewi, M. U. (2016). Pengaruh karakteristik ibu terhadap pemberian asi eksklusif pada bayi usia 0-6 bulan di bpm nurul trianawati, sst surabaya. Jurnal Ilmiah Kesehatan, 9(2), 146-150.

KemenkesRI. (2019). Data dan informasi profil kesehatan Indonesia. Jakarta: 2019.

Kim, E., Singh, K., \& Weiss, W. (2019). Maternal postnatal care in Bangladesh: a closer look at specific content and coverage by different types of providers. Journal of global health reports, 3 .

Sohimah, \& Lestari, Y. A. (2017). Analisis faktor yang mempengaruhi pemberian air susu ibu (asi) eksklusif di wilayah kerja puskesmas cilacap tengah i kabupaten cilacap tahun 2017. Jurnal Ilmiah Kebidanan, 8(2), 125-137.

Umami, W., \& Margawati, A. (2018). Faktor-faktor yang mempengaruhi pemberian ASI eksklusif. JurnalL Kedokteran Diponegoro, 7(4), 1720-1730.

Windarti, Y., \& Dewi, U. M. (2020). Intensive care of the puerperium (icp) impact on the postpartum self-careability in wonokromo. SIKLUS: Journal Research Midwifery Politeknik Tegal, 9(1), 1-5. 